\section{REVISTA BRASILEIRA DE QUALIDADE DE VIDA}

\title{
Entrevista realizada com Maria Cecilia de Souza Minayo
}

\author{
Camila Lopes Ferreira \\ Universidade Tecnológica Federal do Paraná - UTFPR - Curitiba - Brasil \\ cmilalf@gmail.com \\ Luiz Alberto Pilatti \\ Universidade Tecnológica Federal do Paraná - UTFPR - Curitiba - Brasil \\ lapilatti@utfpr.edu.br
}

Maria Cecilia de Souza Minayo possui graduação em Sociologia pela Universidade Federal do Rio de Janeiro (1978), graduação em Ciências Sociais - City University of New York (1979), mestrado em Antropologia Social pela Universidade Federal do Rio de Janeiro (1985) e doutorado em Saúde Pública pela Fundação Oswaldo Cruz (1989). Desde 1997 é Editora Científica da Revista Ciência \& Saúde coletiva da Associação Brasileira de Saúde Coletiva (ABRASCO) e pesquisadora titular da Fundação Oswaldo Cruz. Tem experiência na área de Saúde Pública, com ênfase em Saúde Coletiva, atuando como professora, pesquisadora e orientadora principalmente nos seguintes temas: metodologia de pesquisa social, metodologia da pesquisa social em saúde pública, violência e saúde, causas externas, violência, saúde coletiva e saúde e sociedade. É membro do Conselho Editorial de 13 revistas científicas, sendo 4 estrangeiras e desde 2013 é Editora Regional da Revista Environmental Health Perspectives.

Ressalta-se que foi mantida a entrevista na íntegra, visando preservar a originalidade do depoimento gentilmente oferecido pela entrevistada, a qual agradecemos enormemente de antemão.

1. Poderia contar um pouco acerca de sua trajetória acadêmica que lhe permitiu chegar à condição de pesquisadora $1 \mathrm{~A}$ do CNPq e como editora de um dos mais importantes periódicos do Brasil, a Revista Ciência \& Saúde Coletiva?

Minha trajetória como a de qualquer pesquisador ou pesquisadora que consegue chegar ao topo da carreira é marcada pela dedicação integral nas 'quase' 24 horas diárias aos temas que estuda - digo isso não como exagero mas no sentido de que estamos sempre ligados - a lecionar (ação na qual mais se aprende), a orientar de forma dialógica, a participar da política de ciência e tecnologia e a trabalhar em equipe.

Ajudar a aprimorar a formação das pessoas e trabalhar coletivamente, reconhecendo o mérito de todos que atuam junto com você são dois pontos fundamentais da carreira acadêmica.

Já o trabalho com a Revista Ciência \& Saúde Coletiva é um labor de 18 anos, quando fui escolhida pela ABRASCO para fundar a Revista. Ela começou pequena e pobre com dois números anuais para os quais eu tinha que, inicialmente, convidar autores. No início e até hoje luto por financiamento. Hoje publicamos 12 números por ano e se houvesse dinheiro e mais infraestrutura poderíamos publicar um a cada 15 dias, pois recebemos mais de 2000 originais por ano. É claro que 
se trata também de uma tarefa coletiva, em que todas as pessoas que trabalham atuam colaborativamente e dão a alma.

Investi fortíssimamente na indexação o que às vezes é difícil, complicado, frustrante, mas conseguimos estar nas bases internacionais mais importantes do mundo. Isso é fundamental para a circulação internacional da Revista e vamos aos pouco aprimorando métodos, foco e política de internacionalização sem arredar pé do que significa uma revista de Saúde Pública Brasileira que precisa pensar os problemas nacionais.

2. Seu artigo 'Qualidade de vida e saúde: um debate necessário' foi publicado em 2000 e se tornou um dos artigos mais citados na área de Qualidade de Vida no Brasil. Mais de uma década depois, como a senhora avalia as transformações ocorridas? Pode-se dizer que estas promoveram alguma evolução?

Hoje o conceito de qualidade de vida se tornou mais preciso com a criação de indicadores gerais e também aproximativos da realidade. Por exemplo, mede-se a qualidade de vida em São Paulo, no Rio de Janeiro, em Porto Alegre e para uma dessas cidades são escolhidos indicadores universais e também os que fazem sentido para o contexto.

No campo da saúde, o conceito está muito voltado à reabilitação de pessoas que sofreram doenças ou a grupos específicos como pessoas com deficiência e pessoas idosas. Mas em todos os casos, tanto do ponto de vista social como de saúde o conceito é aproximativo, é apropriado de formas diferentes pelos segmentos, está referido à cultura e tem um grau de subjetividade bastante grande. Por exemplo, um dos grupos sociais que estudamos ultimamente são os policiais civis e militares e trabalhamos com vários indicadores de qualidade de vida que ao mesmo tempo os tornassem comparáveis a qualquer outra categoria, mas que também levasse em conta a especificidade de sua condição de vida e de trabalho.

\section{Um dos objetos de estudo que a senhora tem se debruçado é a violência. Gostaria que comentasse sobre a influência da violência na saúde e na qualidade de vida das pessoas.}

O tema da violência meio que caiu no meu colo. Não fui eu que o escolhi, ele me escolheu. Estávamos saindo da ditadura militar e começamos a enxergar que não era apenas a violência política que existia no país. Os dados epidemiológicos davam conta disso. A Fiocruz me pediu para liderar um grupo de pesquisa que não apenas "contasse" os mortos e lesionados, mas que compreendesse o processo social e histórico no qual o fenômeno vicejava. A violência social crescia e cresceu insistentemente nos anos de 1980 até meados de 1990 quando então se estabilizou em patamares muito elevados. A área da saúde começou a sentir esse crescimento e no início dos anos 1990 passamos a investir nos estudos sobre a questão. Para se ter ideia, a violência hoje é a terceira causa de morte da população em geral e a primeira na extensa faixa etária de 5 a 49 anos.

Criamos o Claves (Centro Latino Americano de Estudos sobre Violência e Saúde) que hoje é um Centro de Referência nacional e internacional em pesquisa, ensino e consultoria sobre o impacto da violência sobre a saúde. Assim, primeiramente, tivemos que investir em compreender que a violência não é apenas a criminalidade. Pois ela é um fenômeno presente na vida brasileira nas famílias, nas escolas, nas relações de gênero, no trabalho e em todos os grupos sociais. Entendemos também que cada um de nós tem seu lado violento, mesmo quando pensamos que só o "outro" é violento.

Nós da área da saúde entramos nesse debate com uma especificidade: trabalhamos não com a punição dos agressores como é o caso da polícia e da justiça, mas com as vítimas e também os agressores na construção de relações saudáveis, com a superação do medo, da dor e da crueldade. Trabalhamos com a ideia de que ser contra a violência é ser a favor da cidadania, do respeito ao 
outro, do diálogo, da inclusão social. E que a violência como um problema social e cultural é aprendido e, portanto, pode ser desconstruído.

\section{Em sua opinião, quais são os reais desafios para que a população brasileira alcance níveis mais elevados de Qualidade de Vida $(\mathrm{QV})$ ?}

Do meu ponto de vista, a chave de tudo está em duas questões fundamentais: (1) diminuição das desigualdades que constituem um fulcro de onde partem todos os problemas sociais e culturais; e (2) educação de qualidade que permite alavancar a consciência social e a transformação das condições de vida. É claro que há uma infinidade de outros problemas, mas esses dois, a meu ver, são cruciais. Investir nesses temas é atuar contra a violência e a favor da qualidade de vida.

\section{Algumas considerações a serem colocadas no tópico 'Palavras Finais'.}

Gostaria de finalizar lembrando o nosso papel como cientista no investimento pessoal e institucional para que a população brasileira tenha melhores condições e qualidade de vida, segundo nossas possibilidades e potencialidades. Para isso retomo as palavras que Bertold Brecht colocou na boca de seu personagem Galileu em diálogo com seu inquisidor, na peça Galileu Galilei: "eu sustento que a única finalidade da ciência está em aliviar a canseira da existência humana!”. 